\title{
The Odor of Disgust: Contemplating the Dark Side of 2oth-Century Cancer History
}

\author{
Bettina Hitzer (iD \\ Max Planck Institute for Human Development, Germany
}

\begin{abstract}
This article explores how historians of emotions and historians of the senses can collaborate to write a history of emotional experience that takes seriously the corporeality of emotions. It investigates how smell, feelings of disgust, and the moral judgments associated with these feelings were interrelated in 20th-century German cancer history. It demonstrates that this complex decisively shaped the emotional experiences of cancer patients. Uncovering this dynamic is only possible by conjoining the history of emotions with a more expanded version of the history of the senses. The combination reveals that the "odor of disgust" was not an ahistorical constant, but was, both in its parts and as a whole, subject to considerable shifts.
\end{abstract}

\section{Keywords}

cancer, disgust, history of emotions, history of the senses

The turn of the 20th century ushered in new hopes for many cancer patients. Just a few decades before, operations had become possible that would have been either unthinkable or extremely painful at the beginning of the 19th century. But the risks of operating on tumors were still enormously high and the chances of the cancer entering into remission, uncertain (e.g., Aronowitz, 2007, pp. 21-85; Brotons, 2017; Löwy, 2011; Olson, 2002, pp. 9-64; Timmermann, 2014, pp. 11$33)$. Doctors were not the only ones euphoric about the discovery that X-rays and radium rays could stop the growth of tumors. For instance, in August 1909, a young man from Dresden wrote to the Royal Prussian Institute for Infectious Diseases in Berlin to ask whether it was possible that his 55-year-old mother's uterine cancer could be cured or at least alleviated by radium rays. He had heard that they had been used in the United States with some success, he pled. When he was told that radium was likely to deliver neither temporary nor permanent betterment, he immediately composed a second letter inquiring about pain management options, appealing to the recipient:

Furthermore, I would be very grateful if you could also tell me if there are any disinfectants that can eliminate the vexing odor that constantly surrounds my sick mother and that truly poisons the air in the room; some doctors who I have asked for advice on this point were not able to give me a disinfectant. (Otto, 1909, Otto to the Royal Prussian Institute for Infectious Diseases, August 30, 1909)
The young man was told that the "awful odor might perhaps be reduced by flushing the wound with zinc chloride," but only under a doctor's supervision (Otto, 1909, Otto to the Royal Prussian Institute for Infectious Diseases, August 30, 1909). Thus, despite sentiments that progress was being made, the young man and his mother were left alone to deal with a problem that significantly affected the lives of many cancer patients and influenced the emotions felt towards them. Still, the odor exuded by some advanced tumors has received little attention in the historiography of cancer.

For some cancer patients, the stench was just one part of a difficult everyday experience that they could hardly escape; it was smelled by their family members, their caretakers, and their doctors. But even if the problem had been around for centuries, the odor itself and the ways in which it was perceived were not unchanging constants, and the emotions associated with it even less so. Though the Dresden man's description of "poisoned air" suggests he might have felt disgusted, the connection between the odor of tumors and disgust in the 20th century was hardly a given. And it certainly was not as direct as one might perhaps surmise when reading psychological research that identifies the "odor of decay as perhaps the most potent sensory attribute associated with disgust" (Rozin, Haidt, \& McCauley, 2016, p. 822). The shifting moral assessments of disgust over the run of the 20th century are an important component of the history of emotional responses to 
odors more generally (e.g., Miller, 1997; Nussbaum, 2004). Moral reservations stemming from the political exploitation of disgust in the 1930s and 1940s caused it to almost disappear from public discourse after 1945. Only in the last third of the century did it gradually resurface as an object of scientific research and philosophical contemplation. Accordingly, the relation between smell and disgust is the dark side of the history of cancer in the 20th century in two ways: it was a key factor in a morally dubious emotional politics towards cancer patients, and it has been little studied because disgust was long a banned emotion that stood outside of what was considered morally acceptable (Otis, 2019).

In what follows, I will first briefly outline how existing concepts of the history of the senses - especially with regard to smell - might be useful in work on the history of emotions and the emotional experiences associated with particular sensory impressions. I will then explore the changes that odor and smelling have undergone over the last 2 centuries and discuss historical shifts in moral, aesthetic, and scientific perspectives on disgust. Against this background, I will then go into how these changes impacted the way in which cancer patients were treated in Germany. My ultimate aim in tracing these developments is twofold: I want to shed light on some murky aspects of the history of cancer in the 20th century by analyzing how smell, feelings of disgust, and the moral judgments associated with these feelings were interrelated, and I want to elucidate how their varying relations in turn influenced how people interacted with cancer patients. This complex decisively shaped the emotional experiences of cancer patients. At the end, I will extrapolate some more general conclusions about how historians of emotions and historians of the senses can collaborate to write a history of emotional experience that takes seriously the corporeality of emotions.

\section{Sensing, Feeling, and the Moral Order: Intertwined Perspectives}

The history of emotions has firmly established itself as an internationally recognized field of historical research. Surveys of it published over the last few years all reference what has crystallized into a canon of methods in the field (e.g., Boddice, 2018; Plamper, 2017; Rosenwein \& Cristiani, 2018). The canon begins with the social constructivist concept of "emotionology" developed by Peter N. and Carol Z. Stearns (1985), which they employed to analyze socially dominant norms that partially determine how emotions are expressed. The concept was then adapted by Barbara Rosenwein (2002) to study how social groups with shared emotion norms constitute the various "emotional communities" that might coexist in a given society. William Reddy (1997) drew on models from cognitive psychology to investigate the mutual influence that the expression of emotions and the feeling of emotions have on one another. His concept of the "emotive" offers scholars a methodological tool for grasping the expression of emotions as an act in the open-ended "navigation of feelings." Some criticized that the social constructivism of these approaches caused them to lose sight of the body. Monique Scheer (2012) responded by shifting the focus to the bodily "practice" of "doing emotions," while still insisting that the body is socially constructed and culturally trained in its habits and inclinations. Many studies have taken up Scheer's proposal, showing how fruitful the concept of emotional practices can be. Still, criticisms (e.g., Gammerl, Hutta, \& Scheer, 2017) that the history of emotions fails to sufficiently address the role of the body and that it remains informed by an all too cognitive, rulesbased understanding of emotions have not abated.

Some of these criticisms draw on the affect theory of people like Ben Anderson (2014), Brian Massumi (2002), and Nigel Thrift (2008), emphasizing the fleeting, contingent, excessive aspects of bodily affects. Others, such as the history of experience research groups at the University of Tampere (HEX) and in Madrid (HIST-EX), argue that the history of emotions should be situated within the broader category of experience, if for varying reasons. Javier Moscoso (2016), for instance, rejects older conceptions of experience based on empiricism. He understands the history of experience as a history of narrative and narrativity that aims to grasp "the cultural circumstances that allow the configuration of a singularity . . . into a story" (p. 179). As a consequence, he asserts that research on the history of experience should focus on "the material and discursive forms that allow the emotionality of the experience" (p. 188). Rob Boddice (2018, pp. 132-167; see also Boddice \& Smith, in press) foregrounds the materiality and ontogenetic plasticity of the (neuro-)physiological, anatomical, and genetic body in their inquiry into the extent to which the history of emotions should be merged with the history of experience. Boddice and Mark Smith argue that,

[I]t may no longer be useful or justifiable to think in terms of emotions, senses, and even cognition (or mind, or soul) as discrete elements of human experience, but rather to see them all as culturally contingent and dynamically connected parts of an affective whole. (Boddice \& Smith, in press)

This, Boddice suggests, might also make it possible to ditch the problematic historical baggage of the concept of "emotion" (Boddice, 2019, p. 189).

This perspective, too, sees the body as socially molded, though in a different fashion and to a different extent than the concept of the body that lies at the foundation of Scheer's concept of emotional practices. While she thinks that emotions are first brought about by the actions of a body with habits, Boddice and Smith draw on the biocultural model of the body currently on the upswing in the natural sciences. The model assumes that the body is, in many respects, incomplete at birth, and it homes in on the feedback loops between this body and its experiences. Applying the model to emotions, neuroscientist Lisa Feldman Barrett argues that,

Emotions ... are not triggered; you create them. They emerge as a combination of the physical properties of your body, a flexible brain that wires itself to whatever environment it develops in, and your culture and upbringing, which provide that environment. (2017, p. xii)

Recent studies on epigenetics (e.g., Carey, 2012; Meloni, 2018) suggest that this claim is also valid for other experiences and does not just concern the brain. In contrast to the concept of 
emotional practices, this approach also captures emotions and experiences that are not regularly practiced and thus habituated, but that are nevertheless culturally conditioned. In the end, one might say that this plasticity is the counterpart of the metaphors described by Laura Otis that straddle physiology and culture, which "refer to common bodily experiences but use those experiences to convey cultural premises" (Otis, 2019, p. 1). Taken together, the two positions offer a robust lens for understanding the senses as the interface between world and self. They also offer an occasion to reflect on the extent to which the body and the ways it is influenced by its environment predetermine what kind of experiences we can have.

Forging connections between the history of the senses and history of emotions is not new. As early as 1941, Lucien Febvre (1941) — viewed by many (e.g., Boddice, 2018, pp. 134-135; Jütte, 2000, pp. 20-21; Plamper, 2017, pp. 40-48) as one of the forefathers of the history of emotions - brought together emotions and the senses in his concept of the "vie affective." Nevertheless, the history of emotions as it has developed since the work of the Stearns (1985) has made few attempts to wed the two fields in a systematic fashion. This is a bit dumbfounding when one considers the new paths being blazed in the sciences with things like the biocultural model of the body mentioned before. It is all the more remarkable because the anthropology of the senses has for years defined its object in a way very similar to how many historians of emotions define theirs. In the words of David Le Breton (2017), the senses are

$[\mathrm{N}]$ ot only an interiorization of the world, they channel meaning, creating a particular order and organizing a multitude of information ... things only become real upon entering the register of language. This is why, in different parts of the world, people do not see, smell, taste, hear or touch the same things in the same ways. Nor do they experience the same emotions. (p. 17)

The parallel does not simply lend support to analyzing emotions and the senses together, however. It also poses new challenges, because although this approach radically historicizes the emotions and senses and sees them as culturally conditioned, the limits of their history and cultural conditioning are set by the body's materiality and its sensory range, which are themselves historical and plastic. Fusing the emotions and the senses in the concept of experience seeks to do justice to the supposition that they are related through endless feedback loops and resolves the problem of treating them as two entities with two separate histories.

Nevertheless, this is not the approach I take, because I am specifically interested in the historically shifting relation between emotions and sensory perceptions as active yet unstable categories of both knowledge and experience in the 20th century. I do not want to open room for the assumption that the relation between the emotions and senses in this period was constant. The unwarranted conclusion (Miller, 1997, p. 7) that bad smells necessarily imply disgust - a seemingly intuitive belief-should be avoided. I thus stick with distinguishing between a historically specific emotion - disgust - from a situated sensory impression-smell-and treat the moral sentiments that might be associated with disgust as a third category in my analysis of the history of cancer in the 20th century. My aim is to elucidate the transformations in the relationships between all three categories and to demonstrate how they influence one another in varying ways and degrees. Keeping them apart fosters insights into the different sensations, emotions, and moral judgments occasioned by cancer and the varying relations that they had to one another. Moreover, this method (e.g., Moscoso, 2016, p. 178) makes it possible to identify emotions that remained socially unnoticed and thus left few traces in historical source material.

\section{The Smell of Cancer in a Sanitized World}

Reproducing the smell of a place that no longer exists is difficult, if not impossible, even if information on the substances that caused the smell is available. Because even if it were possible to reproduce the precise chemical interactions that caused the smell, we are still confronted with the problem that it tells us little about how people at the time perceived it. Certainly, historian Melanie A. Kiechle writes (2016, p. 24), one might seek to increase the authenticity of the staircases and apartments showcased by the Tenement Museum in New York's Lower East Side by reproducing how they smelled when they were inhabited. But wouldn't visitors experience these smells as strange and gross, while inhabitants were probably accustomed to them and thus hardly noticed them? Understanding how a smell smelled in the past necessitates analyzing the context in which the smelling took place (Smith, 2019a, p. xiv). This includes material factors like the size of a room and its ventilation, but most significant is knowing who smelled the smell, in which smellscape (Porteous, 1985), and what they thought about the meaning of smells. Moreover, the history of the senses teaches that Western societies have gradually attributed less significance to smell since the invention of the printing press in the 15th century. In step with this, the vocabulary for describing smells has also become more meagre (Le Breton, 2017, p. 138).

A look at 19th-century documents on cancer intended for a broad readership reveals a more nuanced picture when it comes to the naming of smells. For instance, multiple entries on "cancer" in encyclopedias and lexicons detailed the procession of the disease and almost always mentioned that many advancedstage tumors would break open the skin and emit an "awful smelling" fluid referred to as "Krebs-Gauche" or "Jauche," or "cancer sanies." The word "Gauche" denoted both the "impure fluid exiting ruined or rotting bodies" and "the fluid excrement" of animals (e.g., Brockhaus, 1815, p. 443; 1817, p. 431; 1824 , p. $453 ; 1827$, p. $287 ; 1835$, p. $343 ; 1845$, p. 377 ; Pierer, 1859 , p. $12 ; 1877$, p. 644$)$. In the second half of the 19 th century, the description "awful smelling" was supplanted by "stinking," thus putting more emphasis on the repulsiveness of the smell ("Allgemeine Realencyklopädie," 1870, pp. 687688; “Allgemeine Realencyklopädie," 1884, pp. 687-688; Meyer, 1865 , pp. 316-318; 1877, pp. 329-340; 1888, pp. 173174; 1897, pp. 665-666; 1907, pp. 609-610; Pierer, 1843, p. 428). Some midcentury encyclopedias also dedicated more 
space to how the "cancer sanies" smelled. For instance, the entry on "Krebs" (cancer) in the 1838 Frauenbibliothek says of uterine cancer:

The softening of the until now painless, very hard, knobby tumor . . . makes itself known through an odorous fluid and an excessive menstrual flow mixed with terrible smelling mucus and pus, which slowly turn into unique, terribly acidic smelling sanies that makes the afflicted immediately identifiable from afar. ("Frauenbibliothek," 1838, p. 302)

Around the same time, another lexicon referred to the "specific, highly disagreeable smell," while others said that the smell became "unbearable" as the cancer progressed (Pierer, 1835, p. 629; see also Meyer, 1851, p. 72; 1859, p. 123).

Thus, most encyclopedia editors in the 19th century seem to have thought it necessary to discuss the bad smell of certain tumors, and many associated its quality with the liquid excrement of animals by using the word "Gauche." The articles also evidence a barely noticeable shift: they increasingly foregrounded the smell's perception by others as a repulsive stench. It seems unlikely that the smell itself changed, because the symptoms of cancer and the methods for treating it did not undergo fundamental changes in the 19th century. True, many internal operations on tumors of people with uterine or intestinal cancer became possible as the 19 th century progressed, as noted before. However, only few women were actually operated on and many who were died during or shortly after the procedure. Thus, it seems reasonable to say that other factors must have been responsible for this shift in encyclopedia descriptions of cancer's smell.

One factor might have been changes in medical theory and practice. In the 18th century, the visual, haptic, and olfactory symptoms of cancer were often described in detail in encyclopedia entries. Knowledge of these symptoms was supposed to help doctors distinguish between different types of cancer and the current stage of its progression, and thus to apply the right treatment, which often involved opening or cauterizing the tumor after localizing it with tinctures. Doctors often assumed that the disease was caused by a dyscrasia, an imbalance of components in the blood. The "Jauche" and its varying manifestations were seen as a symptom of this dyscrasia, and identifying its precise qualities was supposed to help the doctor choose the right treatment (e.g., Krünitz, 1789, pp. 355-423). Traces of these theories can still be found in the encyclopedias of the early 19th century, but they disappeared by midcentury. Entries did continue to discuss different theories on the etiology of the illness, but they abandoned the language of humors and fluid imbalances. Thus, the "Jauche" lost its status as a symptom highly significant for diagnosis and treatment. This, in turn, altered its quality as a smell. This observation is supported by the fact that, in entries after midcentury, references to the "stinking" sanies were almost always rounded out with a remark addressed to doctors treating inoperable patients, advising them that all they could do was "lessen the pain, get rid of the stinking secretions, stop bleeding, bolster the diet" (Meyer, 1907, pp. 609-610). In short, measures taken against the "cancer sanies" were now seen as purely palliative. This changed the noses of doctors, who, over the course of the 19th century, came to exclusively direct their energies towards curing the disease. These shifts in knowledge and treatment demoted the smell from an object of scientific interest into a mere symptom. This probably contributed to the smell of tumors being perceived as repulsive to a greater degree than before.

The "devaluation" of the smell for purposes of diagnosis and therapy was not only traceable to the fact that the theory of the humors lost credence and thus failed to explain what the "cancer sanies" were. Another factor were the discoveries of Louis Pasteur and Robert Koch, which debunked the notion that smells could transmit diseases (Corbin, 1986, pp. 1-4). Widely held until the middle of the century, the miasma theory was stripped of its meaning for medicine and ceased to inform scientific research. Nevertheless, as part of new conceptions of public hygiene that had been developing since the early 19th century, the miasma theory played a key role in altering the smellscape of cities. It spurred many European cities to become more sanitary by draining away wastewater underground, building pipes for drinking water, widening streets, creating innercity parks, passing building regulations requiring better light and ventilation in housing, and separating industry from residential areas (Sarasin, 2011). This transformation of urban space continued after the miasma theory was supplanted by germ theory, because the latter seemed to support these measures just as much as the theory it had replaced. The measures eliminated many bad smells from the urban landscape, or at least reduced their intensity. But at the same time, the reduced presence of odors increased people's sensitivity towards "stinks" given off by wastewater, industrial emissions, and humans passing gas, as countless complaints filed by urban denizens about stenches in cities or on rivers demonstrate (e.g., Jütte, 2019, p. 172; Kiechle, 2017). The complaints also reveal that many people continued to believe that smells could transmit diseases. Health, cleanliness, and bourgeois morals thus came to be strongly associated with an absence of smells, which occasioned a series of endeavors that increasingly deodorized Western cities (Jütte, 2019, p. 185).

The trend towards deodorization also influenced the century's modern hospitals. In the mid-19th century, antiseptic practices to fight germs and bacteria were established in hospitals. Bad smells were no longer perceived as agents of infection, but they were viewed as features of substances that were understood to be infectious, like pus and excrement. Thus, the smells themselves were combatted, while at the same time, the hospital developed its own smellscape that was characterized by the smell of phenol, zinc chloride solutions, iodoform, and other antiseptics (Bleker, 2013, pp. 289-292; Schlich, 2013). In this sanitized world, the stench of "cancer sanies" stood out more than ever, for it reminded people of the real sources of infection: pus and decay. It indicated in at least two ways the limits of modern medicine, which had gained confidence in future progress after recent successes and had become increasingly geared towards curing diseases. First, the stench underscored that some cancers could no longer be operated on or irradiated away, but were terminal. Second, it made clear that the fight against germs 
and their transmission was never-ending. Accordingly, encyclopedia articles from the early 20th century named pain management and the "elimination of stinking secretions" as the last palliative measures that could be undertaken for terminal cancer patients (Meyer, 1927, p. 102).

\section{Odor, Disgust, and Exclusion in the 1920s and 1930 s}

The young man mentioned at the beginning learned first-hand that doctors could not always heal their patients. Doctors increasingly viewed these palliative measures as a problem both for inpatient and outpatient care. Thus, in 1910, the head of the German Interior Ministry's Medical Department and Charité (Friedrich-Wilhelm University's clinic), Professor Martin Kirchner wrote in a petition supporting the establishment of special hospitals for cancer patients:

Patients with cancer in advanced stages, women with uterine cancer, breast cancer, etc. where the tumor grows and then begins to decompose, are agonizing for those around them and for themselves. Sometimes, they cannot be housed anywhere, because the terrible stench that they give off makes it near impossible for them to stay with family or at hospitals. (p. 19)

Nineteen years later, hematologist Hans Hirschfeld used similar language when he wrote that cancer patients "cannot stay in their homes because of the terrible stench that emanates from decomposing tumors or because of the terrifying and disgusting appearance of tumors, particularly those on the face" (1919, p. 1189). And in 1941, Tübingen gynecologist August Mayer (1941) stated: "But isolation is necessary, because the awful stench emanating from the decomposing tumor and the great unrest of terminally ill patients bother other patients and interrupt their sleep" (p. 25).

Doctors seemed to agree that the smell of cancer patients with open wounds was disgusting and that fellow patients and family members could not be expected to put up with it. A series of complaints from hospital archives demonstrates that they had a good sense of their other patients' feelings, even though the patients might have used a different vocabulary to describe their olfactory impressions. The complaint of one cancer patient is particularly dramatic and points to the intermingling of odor and contagion in the perception of laypeople, an association that doctors and medical experts rejected when it came to cancer. The patient in question, a woman, had to spend 8 weeks in recovery at the cancer clinic of Berlin's Charité after undergoing an operation. She wrote (H., M., 1942, H. to the Reich Health Leader, July 22, 1942) that it was unbearable

that those in stable condition must be in the same rooms with seriously ill and dying people, and the plague-like stench of the late stages of this serious illness does not help one get better. Some nights, I could only sleep by putting a moist handkerchief on my face. A patient with a stomach illness next to me vomited multiple times a day because she was so disgusted by the awful smell.

A majority of patients and doctors reacted to the disgust by demanding that cancer patients with open tumors be removed from their rooms or isolated elsewhere. But there were multiple proposals on how to do this.

Many surgeons and internists thought it was obvious that terminally ill cancer patients had nothing to gain at the hospital: they could no longer be cured and they caused disgust. Municipal health administrations shared this sentiment. They thus ordered that these patients be sent to asylums, sometimes expressly referencing the "smell! secretions!," as a leaflet for doctors at Berlin's Robert Koch Hospital put it (1930, p. 24). This solved the issue for the hospitals, but it did not help their terminally ill cancer patients, because the asylums did not provide the kind of comprehensive care required for these patients, even less so than the hospitals expelling them. For instance, hardly any professionally trained nurses and caretakers were employed at the Hufeland Asylum, which became known as the "monopoly asylum for all terminally ill cancer patients in Berlin" in the 1920s and 1930s. The lack of adequate care and facilities was so glaring that the patients not confined to their beds had to help wash and feed those who were (Jakoby, 2006, p. 37). There are no sources that might tell us whether or not they felt disgust in doing so. One reason is that the residents of asylums and hospitals rarely kept diaries. Another is that, as the leaflet from the health authority shows, doctors and health administrators did not care much if these patients suffered from feelings of disgust, because they themselves were considered poor, chronically ill, and frail, and were thus socially marginalized. Moreover, it may have simply seemed inconceivable that people who were seen by society as repulsive or disgusting could themselves feel disgust.

Few people protested against this exclusion of cancer patients and the feelings of disgust that it was premised on. Among those who did was the internist Ferdinand Blumenthal. In 1915, he became the head of the Berlin Institute for Cancer Research at the Charité, first in an acting position and then permanently. Together with the Heidelberger Samariterhaus, it was the only clinic in Germany that was expressly open to terminally ill cancer patients. He admonished his colleagues that it was "completely unacceptable" to "house cancer patients who cannot be operated on in such asylums, which do not have any facilities for treating and caring for them" (Blumenthal, 1928). At the same time, he latched onto the disgust felt by other doctors as an argument to try and convince the Charités Board of Directors to keep the notoriously underfunded cancer research institute open. Without a bit of critical sentiment, he wrote:

If these barracks are closed, then the clinics will have to take these 20 cancer patients into their wards. I do not believe that they are capable of doing so nor do I believe that they want to, because these patients make such an intensely unaesthetic impression on their environmentparticularly in the stench that they emit - that the halls they are placed in will no longer be useable for other patients. (Blumenthal, F., 1924, Blumenthal to Charité Executive Board, March 13, 1924)

Thus, Blumenthal did not question the perception that these cancer patients evoked disgust and should therefore be isolated - he just wanted to help them while they were in isolation (e.g., Mayer, 1941). This included ensuring that professionals tended to their tumors, managed their pain, and tried to cover the stink with deodorants that Blumenthal's colleague Hans 
Hirschfeld (1919) was developing. But disgust remained in the cancer barracks, as the Berlin cancer clinic was called because of its location in two one-story barracks houses. Blumenthal (1928) believed that it would be possible to cope with disgust through "ability, tact, and compassion," while Hans Auler (Auler, H., 1930, Auler to Charité Executive Board, December 5, 1930), who took Blumenthal's job in 1933 after the Nazis forced him into retirement, stated that "overcoming" was a key part of the clinic's work. How exactly all this was supposed to come about, however, was left unarticulated by both doctors.

Most of the discussions in medical textbooks and journals were similarly vague. In the few cases when they addressed the issue at all, they emphasized that doctors and nurses should not "be disgusted by helping" and had to "overcome themselves" through compassion and a sense of duty (Overlander, 2001, pp. 85-86). In doing so, they recapitulated the tradition of overcoming disgust through charity, which had been around since the Middle Ages (Le Breton, 2017, pp. 253-254). Apparently, however, these admonitions were generally received with hesitation, a point underscored by information contained in Hans Auler's response (Auler, H., 1942, Auler to the managing director of the Charité, October 30,1942) to the complaint of the Charité patient from 1942 discussed before: The hospital directors decided to resolve the cancer clinic's decades-long shortage of nurses by forcing some to work there as a punitive measure. Meanwhile, health policymakers and the hospitals' directors remained cold to the idea that disgust in the cancer wards should be mitigated by deodorizing tumors and properly tending to exposed tumors. The few clinics in Germany that did care for terminally ill cancer patients faced dire financial straits after 1933. They were often placed in small spaces with inadequate ventilation, which exacerbated the odor issue considerably (e.g., Hitzer, 2017, pp. 560-567; Voswinckel, 2014).

But the failure of the dictum to overcome disgust by overcoming oneself and practicing compassion probably had more to do with a general reevaluation of the feeling of disgust in the 1920s and 1930s. In context, the suppression of disgust demanded of nurses was an anomaly in this period and was confined to the cancer wards. It diverged from the subtle rhetoric of early detection campaigns and the political and moral sensitivity towards disgust about certain smells that developed between 1914 and 1945.

\section{Cancerous Growths: Early Detection Rhetoric and the Politics of Disgust}

The first early detection campaigns were developed at the end of the 19th century by Königsberg gynecologist Georg Winter. Although initially intended to specifically target uterine and cervical cancer, the model was soon expanded to all types of cancer. The broader application was presented at the 1911 International Hygiene Exhibition in a special section and was set forth by the German Hygiene Museum, which was founded in Dresden a year later. A key element of the campaigns was a skillful rhetoric of disgust that was supposed to arouse visitors' interest.

Wax casts (moulages) and models of tumors were an important component of this strategy. Originally designed to teach medical students, the moulages were real moldings of the tumors of living patients and were painted to match the tumor's exact appearance, thus increasing their reality effect (Schnalke, 1994). They were then appended to a model of a part of the patient's body, which was similarly cast by using a cloth coated in wax. Thus, the model of patient Jane Doe's breast tumor came as close as possible to how it appeared in real life. The form of the model and the awareness that the wax had actually touched the body of the patient invested the moulage with a powerful authenticity.

Models of advanced tumors were regularly selected for exhibitions on cancer. Those responsible for planning the exhibits barely discussed the disgust that these models often evoked in visitors, and they certainly did not problematize the issue. On the contrary, they sought to exploit the models' aura of repulsion and, by extension, their sensational aspect. Their only concerns were whether such images might scare visitors, thus leading them to repress thinking about cancer and avoid early detection examinations (Hitzer, 2017, pp. 228-234). This worry occasioned a reduction in the use of such models in exhibitions in the 1920s and 1930s, and when they were used, they were offset by photos of cured patients. Still, museums did not discuss the effect that their rhetoric of disgust might have on healthy persons' feelings towards cancer patients. Evidence exists that exhibitions not only instrumentalized visual disgust, but also disgusting smells and fears of contamination, and this despite the by then well-known fact that cancer is not contagious. For instance, a program for the traveling exhibition "Kampf dem Krebs" ("Fight Cancer"; Gebhardt, 1933, p. 22) printed in 1933 contains a full-page ad for the laundry detergent Persil that emphasized its "germ killing" properties and described it as having a "vitalizing scent and wonderful purity."

As implied by the word "purity," smell and disgust were closely associated in the early 20th century. Their connection was an important element of the (moral) politics of disgust. Understanding the distinct histories of both the sensation and the emotion makes their convergence unsurprising. As discussed before, in the run of the 19th century, smells came to be associated with impurity and a lack of hygiene, while changes in the urban smellscape made them more noticeable. The notion that other people have a distinct smell had been around since medieval times - the most prominent example being the idea that Jews had a specific smell, the "foetor judaicus." These notions saw an uptick in the 19th century (Le Breton, 2017, p. 168), when they were bestowed with "scientific" legitimacy and epistemological significance. Physiologists like the French doctor Bérillon claimed that every race had its own smell passed along by genetic inheritance just like anatomical features. This concept of "ethnochemistry" gained popular approval in Western societies (Smith, 2019b, p. 188). It fit well with the growing conviction that smells betrayed a truth about the person even if they did not look "different," particularly with regard to their race. Thus, the attempt to cover up one smell with another could be seen as an act of deception, a suspicion that found many adherents, especially in Nazi Germany (e.g., Smith, 2019b, pp. 193-194; Waite, 1993, p. 131).

Nineteenth-century discourses on disgust pointed in a similar direction. In his 1872 book The Expression of the 
Emotions in Man and Animals, Darwin primarily associated disgust with the sense of taste and defined it as an evolutionary adaptation that helped animals avoid ingesting rotten food (Menninghaus, 2000, p. 158). However, many, such as Freud, did not follow him, identifying disgust with the sense of smell. This was also the position of Austrian-British philosopher Aurel Kolnai, who in 1929 wrote one of the most influential interwar texts on disgust. Like the "ethnochemical" belief that smell revealed a truth about other people, Kolnai attributed a "cognitive role" to disgust and distinguished disgust from fear on the grounds that it "has the power to impart directly what may be very clear-sighted partial awareness of its object" (Kolnai, 2004, p. 39). Kolnai identified the "prototypical object of disgust" as "the range of phenomena associated with putrefaction," remarking that "rottenness in a living body has its own special note of the disgustingly gruesome" (pp. 53-54). A few pages later, Kolnai makes clear that he was thinking of tumors when elaborating on the "disgust aroused by disease and by bodily deformation" (p. 62). The primary cause of this species of disgust is "an unfamiliar and exaggerated living growth (a tumor, an ulceration, an abscess) which at the same time is already shading off into decomposition" (p. 62). Gottfried Benn's poem "Man and Woman Go Through the Cancer Barracks" (1912/1975) offers a further example. Received as extremely controversial when it was published in 1912, the poem was probably based on Benn's experiences as a doctor at Berlin's Charité hospital. It reads like an accompanying illustration to Kolnai's text. Benn, too, emphasized the repulsiveness of the smell in the lines: "Bed stinks alongside bed. The nurses change shifts hourly" (Benn, 1912/1975, p. 14; see also Charles, 2000; Voswinckel, 2014, pp. 146-147). Evocative of disgust, the decay blinds the narrator to the humanity of the cancer patients: "Look, this lump of fat and rotting fluids" (Benn, 1912/1975, p. 15). Describing cancer as the concrete manifestation of disgust itself seems to have been not all too novel for the culture of the period.

But Kolnai did not rest with a phenomenology of disgust. He went further by asserting that the physically disgusting and the morally disgusting had a "substantial equality of essence" (2004, p. 80), and he identified everything that exhibits softness, formlessness, and the "stupefying exuberance of life" emitted by rotting things as disgusting in both senses (p. 71). This perspective meshes with other interwar antimodernist critiques of decadence (see Menninghaus, 2000, p. 162; Nussbaum, 2004, p. 110 ), which privileged all things hard, masculine, and authoritarian. Even though Kolnai admitted that disgust should be suppressed by compassion "in charitable service," a position that set him apart from thinkers like Nietzsche, he lambasted demands that disgust with other people as such be overcome, harping on the "undeniable cognitive and selective task of disgust from the standpoint of biology, metaphysics, and ethics" (2004, p. 89).

Thus, Kolnai fused smell and disgust by identifying them with a common function in the moral mind. The "stinking" tumor, epitome of the physically disgusting, was cast into a morally dubious position, which was exploited in political rhetoric. In Germany and elsewhere, people deemed "freeloaders" and phenomena deemed bad for society were described as "cancerous tumors." Anti-Semites in Germany made liberal use of the insult to degrade Jews in the 1920s and 1930s, adopting Kolnai's language by maligning them as "soft" and "slimy" (Nussbaum, 2004, p. 110; see also Ehrenreich, 1999; Gilman, 1991; Haibl, 2000; Schwerendt, 2009). This close association of "the Jew" and "cancerous tumors" took the older concept of the "foetor judaicus" to a new extreme. In turn, Jews were made into a metaphor for cancerous cells. Thus, in his lectures, radiologist Hans Holfelder depicted cancer cells as miniature Jews and the X-rays attacking them as SS officers (Proctor, 2002, pp. 59-60).

Though this language made tumors and "the Jew" - and not cancer patients themselves - into metaphors of disgust and decay, we might still ask whether it had an effect on the emotional experience of cancer patients and the emotions that others felt towards them. After all, consensus held that a key feature of things considered disgusting was their capacity to infect through touch or proximity. Given that prejudgment, how could people who bore the markers of disgust on their bodies not appear disgusting to others? And how was the compassion demanded of nurses - even by Kolnai-supposed to outweigh their feelings of disgust when a no-holds-barred politics of disgust was being waged outside the clinic, a politics that made tumors and the smell of decay into its primary metaphors? Evidence suggests that this politics of disgust was ultimately successful: not enough nurses could be found to staff the cancer wards, so they had to be placed there as a disciplinary measure; funds for adequate ventilation remained lacking; and the spaces where terminally ill cancer patients were housed got smaller and smaller (Hitzer, 2017, pp. 541568). For some, the stakes of this politics of disgust involved nothing less than terminally ill persons' right to live itself (e.g., Süß, 2003, pp. 297-300; see also Cocks, 2012). Unfortunately, the archives contain few diaries, letters, and other ego documents composed by terminally ill patients in 1920 s and 1930s Germany. One rare example would have been Sigmund Freud, who had been diagnosed with jaw cancer in 1923 and wrote about his cancer experience in letters. But in 1938, he fled via Paris to London after the Nazi annexation of Austria, so as a seriously ill cancer patient he did not live in a country under National Socialist occupation and spent the last year of his life in London. The complaint filed by Charité patient Martha H. discussed before, however, demonstrates that they had to tolerate expressions of disgust from fellow patients and even family members, who vomited, avoided contact, or wished that they would die (Frick, 1977, pp. 44-45). Thus, it is no stretch to assume that they suffered not only from physical pain, the pain caused by radiation treatment, and the fear of death, but also from self-disgust, a lack of human contact, and the fear that they might lose access to treatment altogether. 


\section{The Silencing of Disgust and the Persistence of Odors}

After 1945, references to smell and disgust disappeared almost completely from documents dealing with cancer. Encyclopedia entries stopped mentioning smell as a late-stage symptom. A constant feature of earlier articles was the description of the consistency, color, and smell of secretions, which were deemed common early symptoms; after 1945, they were called "extraordinary" or "abnormal" (Herder, 1954; Meyer, 1983). Only in the Brockhaus (1955) does the adjective "übelriechend" (malodorous) appear once to identify an early symptom. Newly published medical textbooks also said little on this point, and not just when it came to cancer (Overlander, 2001, pp. 85-86). Nursing journals almost entirely dropped the topic between 1945 and 1980, even though the treatment of cancer pain and terminal care were regularly written on (see journals Die Agnes Karll-Schwester [The Agnes Karll Nurse], Die Diakonieschwester [The Deaconess Sister], Die Evangelische Krankenpflege [The Lutheran Nursing], Der Krankendienst [The Service for the Sick], and Deutsche Schwesternzeitung [German Nurses' Journal]). Only an article from 1951 on inhome care for cancer patients claimed that feelings of "horror and disgust" were normal for nurses caring for people suffering from abdominal cancer. It admonished them to "suppress the feeling of increasing disgust without allowing it to be perceived in the least" (Schroeder, 1957, p. 253). Finally, medical journals, too, stopped discussing the connection of cancer and smell (except for Zabel, 1951).

A simple explanation of the almost complete lack of references to disgust towards cancer might be that cancer simply smelled less. However, a closer look shows that things were not quite that straightforward. Improvements in radiotherapy meant that there were less tumors that exuded a strong odor, while the smells given off by destroyed tissue or bedsores could be more effectively prevented through better hygiene (Hitzer, 2017, pp. 517-518; see also Jacob, 2016). Moreover, hospital spaces were enlarged and outfitted with better ventilation in the run of the 1950s. However, such progress was generally limited to large hospitals, university clinics, newly constructed radiotherapy departments, and later, special tumor care centers. And even in these places, there continued to be cases where smells could not be avoided, among them certain cases of abdominal cancer. Still today, the smell emanating from certain forms of mouth cancer cannot be effectively dampened. Thus, the near silence on how to deal with these smells and the feelings of disgust that they might evoke in doctors and nurses cannot be explained by the decreased frequency of the issue itself. A shift in assessments of what disgust meant also played a role here.

This interpretation is supported by the fact that disgust and how to deal with it also dropped off the radar in other areas of medicine. Indeed, the few mentions of the topic contained in textbooks can mostly be read as recommendations that nurses not talk about it at all. For instance, one widely used textbook that continued to be reprinted in new editions through the 1970s states: "Nurses may not allow anyone to notice any signs of disgust nor may they make a remark about a smell in the presence of a sick patient" (Arbeitsgemeinschaft Deutscher SchwesternverbändeundderDeutschenSchwesterngemeinschaft [Working group of the German Nurses' Associations and the German Sisterhood], 1958, p. 60; see also 1965, p. 70; 1967, p. 78). Not only were they directed to overcome feelings of disgust as in the past, but they were also no longer supposed to let them be noticed. How to do this successfully and how it might affect the relationship between doctors, nurses, and the patient was not discussed, however. This was seemingly informed by the enduring loss of legitimacy of ascribing moral significance to the feeling of disgust. Lack of orientation, a dearth of discussion, and perhaps feelings of guilt dominated instead, so that "disgust" was only taken up again in the 1970s by biology, psychology, and philosophy (e.g., Menninghaus, 2000, pp. 174-177; Rozin et al., 2016, p. 815).

It is difficult to say what effect this taboo had on the emotions felt by doctors and nurses caring for terminally ill cancer patients. It is even more difficult to discern the effects it had on the emotional lives of the patients themselves. Because documents from the time say little about this point, memories - despite all methodological reservations about themare the only source that can help us decipher this issue. Consider an interview conducted in 2016 with radiologist Roland Jacob, who was the lead doctor at the radiotherapy clinic in East Berlin's Buch hospital in the late 1970s (Jacob, 2016). Jacob recalled a woman with abdominal cancer who, despite the best attempts to clean and deodorize her wounds, exuded such a strong smell that it "unsettled us." Her entire home "stank from high to low" and she was "rotting on the inside"; only the hospital minister could tolerate being in a room with her for more than an hour. Right after saying this, however, Jacob emphasized that the case was unique: "Smell didn't play a big role." Only when pressed did he recount the woman's whole story, in which staying silent about disgust did play a central role.

Her husband called Jacob one day and asked him for help. She had ingested a bunch of sleeping pills with the help of her husband in an attempt to commit suicide. Because neither knew how many pills were necessary, she ended up taking a nonfatal dose and was just unconscious. When Jacob heard about the attempted suicide, he had not been surprised: "And you know," he told the interviewer, "I've got to be honest with you, I understood, with the stench, the whole apartment, you know" (Jacob, 2016). When Jacob came to transport the woman to the hospital, her husband gave him a tape that she had recorded before the suicide attempt. Jacob had asked her to write down her experiences and feelings for a book on the psychology of cancer patients that he was working on. Hearing the tape was shocking for the doctor:

The whole thing was a cry for help, a plea to not give up on her because of the stench, but rather to communicate with her. The tape, I cried when I heard it, I'm telling you. I had totally misunderstood. Yeah, I thought she wanted to kill herself, but she only wanted to commit suicide in order to no longer bother those around her. (Jacob, 2016) 
She was resuscitated. Later on, Jacob talked with her about the feeling of disgust. She ultimately succumbed to her cancer in the hospital.

The recollection suggests that disgust felt towards the smell was just suppressed - it didn't disappear. It remained repulsive enough for the doctor to believe that the woman's disgust with herself was a natural consequence of her "disgusting" smell. The consequences of a lack of discussion about disgust made themselves clear here. After the feeling was stripped of its moral authority, the politics of disgust was supplanted by a morally charged taboo against disgust. Thus, the doctor's disgust remained unspoken, while the woman perceived the disgust felt towards her by others even without them saying anything about it. This was detrimental for her emotional life, leading to the failed suicide attempt.

\section{The Sense(s) of an Emotion}

In his Anatomy of Disgust (1997), philosopher of law William Ian Miller dedicates an entire chapter to the relationship between disgust and the sense of smell. One example he works with to illustrate his claims is a section of George Orwell's 1937 book on the lives of the working class in industrial England, The Road to Wigan Pier. Orwell (2001) inquires into why middleclass people cannot be real communists. His answer: "The lower classes smell" (p. 197). He explained: "For no feeling of like or dislike is quite so fundamental as a physical feeling. Racehatred, religious hatred, differences of education, of temperament, of intellect, even differences of moral code can be got over; but a physical repulsion cannot" (p. 198). Orwell's attempt to resolve the question led him to explore what caused the "stink" of the underclasses. But, as Miller writes:

Just because an odor might be socially constructed does not mean it is not there. Even if the smell was invented ... that did not make the smell go away. It was still there as long as the structures that gave rise to it were. (Miller, 1997, p. 248; for a critique of the "realness" of smell, see Smith, 2006)

The smell of exposed tumors and some advanced cases of cancer is a smell that probably responds less to changes in outside structures and social perceptions than did the smell of the British working classes in the 1930s. Despite advances in therapy and hygiene, it hasn't disappeared, though it did become less common over the course of the 20th century. At the same time, how it is perceived underwent qualitative changes in the run of the last 2 centuries. Factors in this shift include new spatial arrangements, changes in the city smellscape, and changes in social, moral, and political positions that associated the smell with the feeling of disgust in various ways. Indeed, the connection between the smell and the feeling existed throughout the 20th century, but its definition transformed in step with changing conceptions of what disgust is, what its purpose is, and whether or not it constitutes a moral sentiment. The offensive politics of disgust and its metaphors of "rot" and "decay" reinforced the disgust felt towards the smell of some cancer patients, contributing to their isolation and exclusion in the years between 1918 and 1945. Though some believed that the feeling should be repressed out of compassion, this changed little in reality. After 1945, disgust was tabooed. But it still persisted. Often mixed with feelings of guilt, it could have fatal consequences. Uncovering this dynamic in historical research is only possible by conjoining the history of emotions with a more expanded version of the history of the senses. The combination reveals that the "odor of disgust" was not an ahistorical constant, but was, both in its parts and as a whole, subject to considerable shifts over the course of time.

This is also true of the history of cancer, which is still undergoing changes today. Since the 1970s, disgust has again become a topic of interest for psychologists and biologists (Rozin et al., 2016, p. 815). Philosophical aesthetics has produced a wealth of literature on it since the publication of Julia Kristeva's Powers of Horror: An Essay on Abjection (1982; see also Menninghaus, 2000, p. 174), while artists exhibit excrement and pus as "abject art." Nursing has also begun to grapple with disgust. Today, the dominant position is that feeling disgust is "okay," but that, following contemporary theories of emotions, nurses must both allow the "overwhelming" emotion to flow and must consciously manage it (Albrecht \& Keßler, 2006; Jettenberger, 2017; Krey, 2015; Kuratorium Deutsche Altershilfe [Board of Trustees German Old Age Aid], 1996; Ringel, 2011). That disgust has shed its taboo status might also have to do with the contemporary revaluation of smell and the olfactory senses. Aromatherapy shows that some smells can be relaxing and have health benefits. Other smells carry pheromones that can influence behavior even if they are not consciously registered (Jütte, 2019, pp. 183-186). These developments have recovered smell from its status as one of the "lower" senses and revealed new ways in which smell affects the body. For a few years now, medical professionals have been discussing the extent to which altered bodily odors can serve as an early indicator of a budding illness, including cancer. Dogs allegedly have a particularly refined ability to sense an onset of cancer (e.g., Guirao Montes et al., 2017; Yoel, Gopas, Ozer, Peleg, \& Shvartzman, 2015). And surprisingly, it is precisely these animals with sensitive noses that do not react with disgust to the smell of serious mouth cancers. As a result, dogs are now employed as aid animals in palliative care units (Holch, 2017). Psychologists agree that the connection between smell and disgust is not a biological given and that babies and toddlers learn to feel disgusted by certain smells. In other words: "In the absence of any socializing agents, it seems that core disgust might not emerge on its own. ... [But it is] easy to acquire because of an evolved predisposition" (Rozin et al., 2016, pp. 823-824). It might even be possible for the mutual relation between "odor" and "disgust" to be entirely broken, as mortician Alfred Riepertinger writes about his own experience with dead bodies: "Nature gave me an excellent olfactory sense: I can sense smells very well, but such smells of decay don't affect me in the least" (Seul, 2016).

\section{Declaration of Conflicting Interests}

The author declared no potential conflicts of interest with respect to the research, authorship, and/or publication of this article. 


\section{ORCID iD}

Bettina Hitzer (iD https://orcid.org/0000-0003-3683-3170

\section{References}

Albrecht, M., \& Keßler, J. (2006). Ekel - ein Tabuthema - Allgemeine Theorie und Praxis des "Sich-Ekelns" in der Pflege [Disgust - A taboo topic - General theory and practice of "disgust with oneself" in medicine and nursing]. Norderstedt, Germany: Grin Verlag.

Allgemeine Realencyklopädie, oder Conversationslexikon für alle Stände (Universal encyclopedia for all estates). (1870). (3rd ed., Vol. 8). Regensburg, Germany: Mainz.

Allgemeine Realencyklopädie, oder Conversationslexikon für alle Stände (Universal encyclopedia for all estates). (1884; Vol. 8). Regensburg, Germany: Manz.

Anderson, B. (2014). Encountering affect: Capacities, apparatuses, conditions. New York, NY: Routledge.

Arbeitsgemeinschaft Deutscher Schwesternverbände und der Deutschen Schwesterngemeinschaft (Working group of the German Nurses' Associations and the German Sisterhood). (Ed.). (1958). Die Pflege des kranken Menschen: Lehrbuch für Krankenpflegeschulen [Caring for the ill: A textbook for nursing schools]. Stuttgart, Germany: W. Kohlhammer.

Arbeitsgemeinschaft Deutscher Schwesternverbände und der Deutschen Schwesterngemeinschaft (Working group of the German Nurses' Associations and the German Sisterhood). (Ed.). (1965). Die Pflege des kranken Menschen: Lehrbuch für Krankenpflegeschulen [Caring for the ill: A textbook for nursing schools] (5th ed.). Stuttgart, Germany: W. Kohlhammer.

Arbeitsgemeinschaft Deutscher Schwesternverbände und der Deutschen Schwesterngemeinschaft (Working group of the German Nurses' Associations and the German Sisterhood). (Ed.). (1967). Die Pflege des kranken Menschen: Lehrbuch für Krankenpflegeschulen [Caring for the ill: A textbook for nursing schools] (6th ed.). Stuttgart, Germany: W. Kohlhammer.

Aronowitz, R. A. (2007). Unnatural history: Breast cancer and American society. Cambridge, UK: Cambridge University Press.

Auler, H. (1930, December 5). [Letter to the Charite Executive Board]. Humboldt University Archives (File No. 953, p. 108), Berlin, Germany.

Auler, H. (1942, October 30). [Letter to the managing director of the Charité]. Humboldt University Archives, Charité-Direktion Collection (File No. 2724, p. 183), Berlin, Germany.

Barrett, L. F. (2017). How emotions are made: The secret life of the brain. London, UK: Macmillan.

Benn, G. (1975). Gesammelte Werke in acht Bänden [Collected works in eight volumes]. Munich, Germany: Dt. Taschenbuch Verlag. (Original work published 1912)

Bleker, J. (2013). Antisepsis in Deutschland. Zur Wissenschaftsgeschichte der Chirurgie 1872-1892 [On the scientific history of surgery 18721892]. Medizinhistorisches Journal, 48(3-4), 273-305.

Blumenthal, F. (1924, March 13). [Letter to Charité Executive Board]. Humboldt University Archives, Charité-Direktion Collection (File No. 951, p. 174), Berlin, Germany.

Blumenthal, F. (1928). Gründung und Aufgaben der Krebs-Institute [Founding and tasks of the cancer institutes]. Sonderdruck: Archiv Für Soziale Hygiene und Demographie, 3(3), 48-49. German Federal Archives (File No. 1501/126318), Berlin, Germany.

Boddice, R. (2018). The history of emotions. Manchester, UK: Manchester University Press.

Boddice, R. (2019). A history of feelings. London, UK: Reaktion Books.

Boddice, R., \& Smith, M. M. (in press). Emotion, sense, experience. Cambridge, UK: Cambridge University Press.

Brockhaus. (1815). Conversations-Lexicon oder encyclopädisches Handwörterbuch für gebildete Stände [Encyclopedia for the educated estates] (3rd ed., Vol. 5). Leipzig, Germany: Author.
Brockhaus. (1817). Allgemeine Hand-Encyklopädie für die gebildeten Stände in alphabetischer Ordnung und in zehn Bänden [Universal encyclopedia for the educated estates in alphabetical order and in ten volumes] (4th ed., Vol. 5). Altenburg, Germany: Author.

Brockhaus. (1824). Allgemeine deutsche Real-Encyclopädie für die gebildeten Stände: Conversations-Lexicon [Universal German encyclopedia for the educated estates] (6th ed., Vol. 5). Leipzig, Germany: Author.

Brockhaus. (1827). Allgemeine deutsche Real-Encyclopädie für die gebildeten Stände: (Conversations-Lexicon) [Universal German encyclopedia for the educated estates] (7th ed., Vol. 6). Leipzig, Germany: Author.

Brockhaus. (1835). Allgemeine deutsche Real-Encyclopädie für die gebildeten Stände: (Conversations-Lexicon) [Universal German encyclopedia for the educated estates] (8th ed., Vol. 6). Leipzig, Germany: Author.

Brockhaus. (1845). Allgemeine deutsche Real-Encyclopädie für die gebildeten Stände: Conversations-Lexicon [Universal German encyclopedia for the educated estates] (9th ed., Vol. 8). Leipzig, Germany: Author.

Brockhaus. (1955). Der Große Brockhaus [The grand Brockhaus encyclopedia] (16th ed., Vol. 6). Wiesbaden, Germany: Author.

Brotons, F. H. (2017). The experience of cancer illness: Spain and beyond during the second half of the nineteenth century (Unpublished doctoral dissertation). Universidad Carlos III de Madrid, Madrid, Spain.

Carey, N. (2012). The epigenetics revolution: How modern biology is rewriting our understanding of genetics, disease, and inheritance. New York, NY: Columbia University Press.

Charles, K. A. (2000). Gottfried Benn's medical exotics: Proximities in literature, the body and ethos (Unpublished doctoral dissertation). University of Minnesota, Minneapolis, MN.

Cocks, G. (2012). The state of health: Illness in Nazi Germany. Oxford, UK: Oxford University Press.

Corbin, A. (1986). The foul and the fragrant: Odor and the French social imagination. Cambridge, MA: Harvard University Press.

Darwin, C. (1872). The expression of the emotions in man and animals. London, UK: John Murray.

Ehrenreich, M. (1999). Zerrbild und Wunschbild. Zur Darstellung der Juden in der nationalsozialistischen und jüdischen deutschsprachigen Kinderund Jugendliteratur des Dritten Reichs [Distortion and desire: On the representation of Jews in National Socialist and Jewish German-language children and young adult literature in the Third Reich]. Regensburg, Germany: Regensburger Skripten zur Literaturwissenschaft.

Febvre, L. (1941). La sensibilité et l'histoire: Comment reconstituer la vie affective d'autrefois? [Sensibility and history: How to reconstitute the emotional life of the past]. Annales d'histoire sociale, 3(1-2), 5-20. https://doi.org/10.1017/S1243256300003522

Frauenbibliothek. Oder Handbuch aller Kenntnisse, welche das weibliche Geschlecht in jedem Alter, Stand und Verhältnisse, in Beziehung auf die Wirthschaft, als Ehefrau und Mutter und in der Stellung zum Gesinde zu wissen nöthig hat (Women's library. Or, encyclopedia of all knowledge about economics that the female sex of every age, estate, and relation needs to know in her capacity as wife, mother, and manager of servants). (1838). (Vol. 5). Berlin, Germany: Lewent.

Frick, H. (1977). Die blaue Stunde [The blue hour]. Munich, Germany: Bertelsmann.

Gammerl, B., Hutta, J. S., \& Scheer, M. (2017). Feeling differently: Approaches and their politics. Emotion, Space and Society, 25, 87-94. https://doi.org/10.1016/j.emospa.2017.07.007

Gebhardt, B. (1933). Kampf dem Krebs [Fight cancer]. Dresden, Germany: Verlag für Volkswohlfahrt.

Gilman, S. L. (1991). The Jew's body. New York, NY: Routledge.

Guirao Montes, Á., Molins López-Rodó, L., Rodríguez, I. R., Dequigiovanni, G. S., Viñolas Segarra, N., Marrades Sicart, R. M., . . . Agustí García-Navarro, Á. (2017). Lung cancer diagnosis by trained dogs. European Journal of Cardio-Thoracic Surgery, 52(6), 1206-1210. https://doi.org/10.1093/ejcts/ezx152

H., M. (1942, July 22). [Letter to the Reich Health Leader]. German Federal Archives (File No. 4901/1341, pp. 41-42), Berlin, Germany. 
Haibl, M. (2000). Zerrbild als Stereotyp: Visuelle Darstellungen von Juden zwischen 1850 und 1900 [Distortion as stereotype: Visual representations of Jews between 1850 and 1900]. Berlin, Germany: Metropol.

Herder. (1954). Der Große Herder: Nachschlagewerk für Wissen und Leben [The great Herder: Encyclopedia for knowledge and life] (5th ed., Vol. 5). Freiburg, Germany: Author.

Hirschfeld, H. (1919). Eugoform, ein neues Deodorans [Eugoform, a new deodorant]. Berliner Klinische Wochenschrift, 56, 1189.

Hitzer, B. (2017). Krebs fühlen. Die Emotionsgeschichte der Krebserkrankung im 20. Jahrhundert [Feeling cancer: The history of cancer and emotions in the 20th century]. Freie Universität Berlin, Berlin, Germany. https://doi.org/10.17617/2.2558364

Holch, C. (2017). Worauf es in der Palliativmedizin ankommt. Die Schrecken am Ende des Lebens [What matters in palliative care. The horrors at the end of life] [Interview with S. Gottschling]. Retrieved from https://chrismon.evangelisch.de/artikel/2017/33169/worauf-esder-palliativmedizin-ankommt

Jacob, R. (2016, November 6). Interview by B. Hitzer [Tape recording; transcript available from the author]. Berlin, Germany.

Jakoby, B. (2006). Das Hospital und Siechenheim Fröbelstraße (1889-1934) [The hospital and infirmary on Fröbel Street (1889-1934)]. In BerlinBrandenburg History Workshop (Ed.), Prenzlauer, Ecke Fröbelstrasse: Hospital der Reichshauptstadt, Haftort der Geheimdienste, Bezirksamt Prenzlauer Berg 1889-1989 [Prenzlauer and Fröbel: The hospital of the imperial capitol, prison of the secret police, Prenzlauer Berg district office 1889-1989] (1st ed., pp. 25-49). Berlin, Germany: Lukas.

Jettenberger, M. (2017). Ekel - Professioneller Umgang mit Ekelgefühlen in Gesundheitsfachberufen [Disgust - Taking a professional approach to feelings of disgust in the medical field]. Berlin, Germany: Springer.

Jütte, R. (2000). Geschichte der Sinne: von der Antike bis zum Cyberspace [The history of the senses: From antiquity to cyberspace]. Munich, Germany: Beck.

Jütte, R. (2019). Reodorizing the modern age. In M. M. Smith (Ed.), Smell and history: A reader (1st ed., pp. 170-186). Morgantown: West Virginia University Press.

Kiechle, M. A. (2016). Preserving the unpleasant: Sources, methods, and conjectures for odors at historic sites. Future Anterior: Journal of Historic Preservation, History, Theory, and Criticism, 13(2), 22-32. https://doi.org/10.5749/futuante.13.2.0023

Kiechle, M. A. (2017). Smell detectives: An olfactory history of nineteenthcentury urban America. Seattle: University of Washington Press.

Kirchner, M. (1910). Ziele und Zwecke des Deutschen Zentralkomitees für Krebsforschung [Aims and purposes of the German Central Committee for Oncological Research]. Sonderabdruck: Zeitschrift Für Krebsforschung, 10(1), 19-21. German Federal Archives (File No. 1501/111967, pp. 19-21), Berlin, Germany.

Kolnai, A. (2004). Disgust. In C. Korsmeyer \& B. Smith (Eds.), On disgust (pp. 29-92). Chicago, IL: Open Court.

Krey, H. (2015). Ekel ist okay: Ein Lern- und Lehrbuch zum Umgang mit Emotionen in Pflegeausbildung und Pflegealltag [Disgust is okay: A textbook for how to deal with emotions in nurses' training and nursing practice] (2nd ed.). Frankfurt, Germany: Mabuse-Verlag.

Kristeva, J. (1982). Powers of horror: An essay on abjection (L. S. Roudiez, Trans.). New York, NY: Columbia University Press.

Krünitz, J. G. (1789). Oekonomische Encyklopädie, oder allgemeines System der Staats- Stadt- Haus- und Landwirtschaft, in alphabetischer Ordnung [Economic encyclopedia, or general system of the state, municipal, household, and farming economies, in alphabetical order]. Berlin, Germany: Pauli.

Kuratorium Deutsche Altershilfe (Board of Trustees German Old Age Aid). (Ed.). (1996). Grenzsituationen in der Pflege: Nähe und Distanz, Schamgefühl und Ekel [Liminal situations in care: Closeness and distance, shame and disgust]. Cologne, Germany: GeroCare.

Le Breton, D. (2017). Sensing the world: An anthropology of the senses. London, UK: Bloomsbury Academic.

Löwy, I. (2011). "Because of their praiseworthy modesty, they consult too late": Regime of hope and cancer of the womb, 1800-1910. Bulletin of the History of Medicine, 85(3), 356-383. https://doi.org/10.1353/ bhm.2011.0058

Massumi, B. (2002). Parables for the virtual: Movement, affect, sensation. Durham, NC: Duke University Press.

Mayer, A. (1941). Die Entwicklung unserer Therapie beim Uterus-Kollumkarzinom [The development of our therapy for uterine cervical carcinoma]. Strahlentherapie, 69, 17-28.

Meloni, M. (2018). A postgenomic body: Histories, genealogy, politics. Body \& Society, 24(3), 3-38. https://doi.org/10.1177/1357034X18785445

Menninghaus, W. (2000). Ekel [Disgust]. In K. Barck, M. Fontius, D. Schlenstedt \& F. Wolfzettel (Eds.), Ästhetische Grundbegriffe (̈̈GB): Historisches Wörterbuch in sieben Bänden [Key concepts in aesthetics: Historical encyclopedia in seven volumes] (Vol. 2, pp. 142-177). Stuttgart, Germany: Metzler.

Meyer. (1851). Das große Conversations-Lexicon für die gebildeten Stände [Grand encyclopedia for the educated estates] (0th ed., Vol. 19). Hildburghausen, Germany: Bibliographisches Institut.

Meyer. (1859). Neues Conversations-Lexikon für alle Stände [New encyclopedia for all estates] (1st ed., Vol. 10). Hildburghausen, Germany: Bibliographisches Institut.

Meyer. (1865). Neues Konversations-Lexikon: Ein Wörterbuch des allgemeinen Wissens [New encyclopedia: A dictionary of general knowledge] (2nd ed., Vol. 10). Hildburghausen, Germany: Bibliographisches Institut.

Meyer. (1877). Meyers Konversations-Lexikon: Eine Encyklopädie des allgemeinen Wissens [Meyer's lexicon: An encyclopedia of general knowledge] (3rd ed., Vol. 10). Leipzig, Germany: Bibliographisches Institut.

Meyer. (1888). Meyers Konversations-Lexikon: Eine Encyklopädie des allgemeinen Wissens [Meyer's lexicon: An encyclopedia of general knowledge] (4th ed., Vol. 10). Leipzig, Germany: Bibliographisches Institut.

Meyer. (1897). Meyers Konversations-Lexikon: Ein Nachschlagewerk des allgemeinen Wissens [Meyer's lexicon: An encyclopedia of general knowledge] (5th ed., Vol. 10). Leipzig, Germany: Bibliographisches Institut.

Meyer. (1907). Meyers Großes Konversations-Lexikon. Ein Nachschlagewerk des allgemeinen Wissens [Meyer's grand encyclopedia: A reference work of general knowledge] (6th ed., Vol. 11). Leipzig, Germany: Bibliographisches Institut.

Meyer. (1927). Meyers Lexikon [Meyer's encyclopedia] (7th ed., Vol. 7). Leipzig, Germany: Bibliographisches Institut.

Meyer. (1983). Meyers Großes Universallexikon [Meyer's grand universal encyclopedia] (5th ed., Vol. 8). Mannheim, Germany: Bibliographisches Institut.

Miller, W. I. (1997). The anatomy of disgust. Cambridge, MA: Harvard University Press.

Moscoso, J. (2016). From the history of emotions to the history of experience: A Republican sailor's sketchbook in the Civil War. In L. E. Delgado, P. Fernández \& J. Labanyi (Eds.), Engaging the emotions in Spanish culture and history (pp. 176-191). Nashville, TN: Vanderbilt University Press.

Nussbaum, M. C. (2004). Hiding from humanity: Disgust, shame, and the law. Princeton, NJ: Princeton University Press.

Olson, J. S. (2002). Bathsheba's breast: Women, cancer, and history. Baltimore, MD: Johns Hopkins University Press.

Orwell, G. (2001). The road to Wigan Pier. London, UK: Penguin Books.

Otis, L. (2019). Banned emotions: How metaphors can shape what people feel. Oxford, UK: Oxford University Press.

Otto, J. (1909, August 30). [Letter to the Royal Prussian Institute for Infectious Diseases]. German Federal Archives (File No. 86/2763), Berlin, Germany.

Overlander, G. (2001). Die Last des Mitfühlens: Aspekte der Gefühlsregulierung in sozialen Berufen am Beispiel der Krankenpflege [The burden of sympathy: Aspects of regulating emotions in social occupations depicted through the example of nursing] (4th ed.). Frankfurt, Germany: Mabuse-Verlag.

Pierer. (1835). Universal-Lexikon oder vollständiges encyclopädisches Wörterbuch [Universal lexicon or complete encyclopedic dictionary] (1st ed., Vol. 11). Altenburg, Germany: Literatur-Comptoir. 
Pierer. (1843). Universal-Lexikon der Gegenwart und Vergangenheit oder neuestes encyclopädisches Wörterbuch der Wissenschaften, Künste und Gewerbe [Universal lexicon of the present and past, or the newest encyclopedic dictionary of the sciences, arts, and commerce] (2nd ed., Vol. 16). Altenburg, Germany: Author.

Pierer. (1860). Pierer's Universal-Lexikon der Vergangenheit und Gegenwart oder Neuestes encyclopädisches Wörterbuch der Wissenschaften, Künste und Gewerbe [Pierer's universal lexicon of the present and past, or the newest encyclopedic dictionary of the sciences, arts, and commerce] (4th ed., Vol. 9). Altenburg, Germany: Author.

Pierer. (1877). Pierers Universal-Conversations-Lexikon: Neuestes encyclopädisches Wörterbuch aller Wissenschaften, Künste und Gewerbe [Pierer's universal conversational lexicon: Newest encyclopedic dictionary of the sciences, arts, and commerce] (6th ed., Vol. 11). Oberhausen, Germany: Spaarmann.

Plamper, J. (2017). The history of emotions: An introduction (K. Tribe, Trans.). Oxford, UK: Oxford University Press.

Porteous, J. D. (1985). Smellscape. Progress in Physical Geography: Earth and Environment, 9(3), 356-378. https://doi. org/10.1177/030913338500900303

Proctor, R. N. (2002). Blitzkrieg gegen den Krebs: Gesundheit und Propaganda im Dritten Reich [Blitzkrieg against cancer: Health and propaganda in the Third Reich]. Stuttgart, Germany: Klett-Cotta.

Reddy, W. M. (1997). Against constructionism: The historical ethnography of emotions. Current Anthropology, 38(3), 327-351. https://doi. org $/ 10.1086 / 204622$

Ringel, D. (2011). Ekel in der Pflege: Eine "gewaltige" Emotion [Disgust in nursing: A "powerful" emotion] (3rd ed.). Frankfurt, Germany: Mabuse-Verlag.

Robert Koch Hospital Berlin-Moabit. (1930). [Leaflet for admission doctors and in-patient physicians]. Archives of the State of Berlin (LAB A Rep. 003-04-03, No. 33, pp. 19-28), Berlin, Germany.

Rosenwein, B. H. (2002). Worrying about emotions in history. The American Historical Review, 107(3), 821-845. https://doi.org/10.1086/ ahr/107.3.821

Rosenwein, B. H., \& Cristiani, R. (2018). What is the history of emotions? Malden, MA: Polity.

Rozin, P., Haidt, J., \& McCauley, C. (2016). Disgust. In L. Feldman Barrett, M. Lewis \& J. M. Haviland-Jones (Eds.), Handbook of emotions (4th ed., pp. 815-834). New York, NY: The Guilford Press.

Sarasin, P. (2011). Die moderne Stadt als hygienisches Projekt. Zum Konzept der "Assanierung" der Städte im Europa des 19. Jahrhunderts [The modern city as a hygienic project: On the concept of "sanitization" of cities in 19th-century Europe]. In M. V. Lampugnani, K. Frey \& E. Perotti (Eds.), Stadt \& Text. Zur Ideengeschichte der Stadt un des Städtebaus im Spiegel theoretischer Schriften (18.-21. Jahrhundert) [City \& text: On the history of the concept of the city and urban planning as reflected in theoretical writings (18th to 21st centuries)] (pp. 99-112). Berlin, Germany: Gebrüder Mann-Verlag.

Scheer, M. (2012). Are emotions a kind of practice (and is that what makes them have a history)? A Bourdieuian approach to understanding emotion. History and Theory, 51(2), 193-220. https://doi.org/10.1111/ j.1468-2303.2012.00621.x

Schlich, T. (2013). Farmer to industrialist: Lister's antisepsis and the making of modern surgery in Germany. Notes and Records of the Royal Society, 67(3), 245-260. https://doi.org/10.1098/rsnr.2013.0032
Schnalke, T. (1994). Die Medizinische Moulage - ein historischer Überblick [Medical moulage - A historical survey]. In S. Hahn \& D. Ambatielos (Eds.), "Wachs-Moulagen und Modelle": Internationales Kolloquium, 26. und 27. Februar 1993 ["Wax - Moulages and models”: International conference, February 26 and 27, 1993] (pp. 13-28). Dresden, Germany: Verlag des Dt. Hygiene-Museums.

Schroeder, P. (1957). Häusliche Pflege Krebskranker [Home care of cancer patients]. Deutsche Schwesternzeitung, 8, 252-254.

Schwerendt, M. (2009). "Trau keinem Fuchs auf grüner Heid, und keinem Jud bei seinem Eid": Antisemitismus in nationalsozialistischen Schulbüchern und Unterrichtsmaterialien ["Trust no fox on the green heath, trust no Jew on his oath": Anti-Semitism in National Socialist schoolbooks and teaching materials]. Berlin, Germany: Metropol Verlag.

Seul, S. M. (2016, May 1). Wenn der Tod süßlich riecht, stinkt was. Laura Rose im Gespräch mit Alfred Riepertinger, Leichenpräparator und Autor von "Mein Leben mit den Toten" [When death smells sweet, something stinks: Laura Rose in discussion with Alfred Riepertinger, undertaker and author of "My life with the dead"] [Web log message]. Retrieved from https://www.autorenwelt.de/blog/federwelt/wenn-der-tod-suesslich-riecht

Smith, M. M. (2006). How race is made: Slavery, segregation, and the senses. Chapel Hill: University of North Carolina Press.

Smith, M. M. (2019a). Editor's introduction: Smelling the past. In M. M. Smith (Ed.), Smell and history: A reader (1st ed., pp. ix-xxiv). Morgantown: West Virginia University Press.

Smith, M. M. (2019b). Making "others" smell. In M. M. Smith (Ed.), Smell and history: A reader (1st ed., pp. 187-201). Morgantown: West Virginia University Press.

Stearns, P. N., \& Stearns, C. Z. (1985). Emotionology: Clarifying the history of emotions and emotional standards. The American Historical Review, 90(4), 813-836. https://doi.org/10.2307/1858841

Süß, W. (2003). Der "Volkskörper" im Krieg: Gesundheitspolitik, Gesundheitsverhältnisse und Krankenmord im nationalsozialistischen Deutschland 1939-1945 [The "body of the nation" in war: Health policy, healthcare, and the murder of sick people in Nazi Germany 1939-1945]. Munich, Germany: Oldenbourg.

Thrift, N. J. (2008). Non-representational theory: Space, politics, affect. London, UK: Routledge.

Timmermann, C. (2014). A history of lung cancer: The recalcitrant disease. New York, NY: Palgrave Macmillan.

Voswinckel, P. (2014). Erinnerungsort Krebsbaracke: Klarstellungen um das erste interdisziplinäre Krebsforschungsinstitut in Deutschland (Berlin, Charité): mit Erstveröffentlichung eines Theaterstücks von Hugo Döblin "Goliath erschlägt David" (1935) [Cancer barracks as a site of memory: On the first interdisciplinary oncology institute in Germany (Berlin, Charité): With the premiere publication of "Goliath Kills David," a play by Hugo Döblin]. Berlin, Germany: Deutsche Gesellschaft für Hämatologie und Medizinische Onkologie.

Waite, R. G. L. (1993). The psychopathic god: Adolf Hitler. New York, NY: Da Capo Press.

Yoel, U., Gopas, J., Ozer, J., Peleg, R., \& Shvartzman, P. (2015). Canine scent detection of volatile elements, characteristic of malignant cells, in cell cultures. The Israel Medical Association Journal: IMAJ, 17(9), $567-570$.

Zabel, W. (1951). Zusätzliche Krebsbehandlung [Supplementary cancer treatment]. Hippokrates, 1, 1-11. 